О. А. Стишов

\title{
СУБСТАНТИВНІ КОМПОЗИТИ-НЕОЛОГІЗМИ В МОВІ СУЧАСНИХ УКРАЇНСЬКИХ ЗМІ
}

Стишов О. А. Субстантивні композити-неологізми в мові сучасних українських ЗМІ. Статтю присвячено вивченню різних типів іменникових інновацій, утворених основоскладанням, на матеріалі мови сучасних українських ЗМІ. Проаналізовано словотворчі, семантичні та стилістичні особливості композитів-неологізмів.

Ключові слова: композит, основоскладання, інновація, неологізм, словотвірчий тип.

Стишов А. А. Субстантивные композиты-неологизмы в языке современных украинских СМИ.

Статья посвящена изучению различных типов инноваций имен существительных, образованных основосложением, на материале языка современных 
украинских СМИ. Проанализованы словообразовательные, семантические и стилистические особенности композит-неологизмов.

Ключевые слова: композит, основосложение, инновация, неологизм, словообразовательный тип.

Styshov O. A. Substantive composite neologisms in the language of modern Ukrainian mass media.

The article is devoted to the research of different types of compoundnouninnovations, based on the material of modern Ukrainian mass media. Wordforming, semantic and stylistic peculiarities of composite neologisms have been analysed.

Key words: composite, composition, innovation, neologism, word formation type.

Фактичний матеріал переконливо свідчить про активізацію в сучасній українській мові різних типів складних слів. Адже словоскладання відіграє важливу роль у номінативному й комунікативному процесах як у літературній мові, так $\mathrm{i}$ в не кодифікованих іiі різновидах - соціальних і авторських субмовах. Воно відбиває загальну тенденцію до зростання складних понять у різних царинах діяльності людини, їі раціонального мислення, світосприйняття, а також почуттів, настроїв тощо. Такі одиниці - свідчення своєрідності певної мови, культури, традицій, менталітету народу - носія цієї мови.

Зарубіжна і українська мовознавча наука має значні напрацювання з вивчення різних типів складних слів із погляду виникнення і розвитку, структури й семантики, їхнього функціонування в різних дискурсах $\mathrm{i}$ стилістичного використання. Характерно, що в останні десятиліття засвідчено значне зацікавлення лінгвістів вивченням різних типів складних слів у мовах (О. Д. Мешков, Л. Ф. Омельченко, Д. О. Квеселевич, C. С. Воробйова, В. А. Карпюк, М. Бліхарський, Р. Гжегорчикова, Х. Ядацька, А. В. Березовенко, В. Л. Варановіч, В. Л. Григор'єв, О. А. Земська, О. С. Кубрякова, Т. І. Кочеткова, О. І. Моісеєв, М. Я. Брицин, О. В. Петров, С. В. Гудилова, О. О. Лапшина, Л. І. Ніколаєнко, К. Хандке, Н. Marchand та багато ін.). Студіюванню названих одиниць в сучасній українській мові присвячено роботи Н.Ф. Клименко, Л. Є. Азарова, К. Г. Городенської, Є. А. Карпіловської, А. М. Нелюби, Ж. В. Колоїз, Г. М. Вокальчук, . М. Віняр, М. П. Годованої, Л. М. Ніколаєнко, І. Я. Мислави-Бунько, М. В. Бойчук та ін. Проте вважаємо, що назване питання в нашій мові потребує більш виваженого й грунтовнішого вивчення, оскільки корпус інноваційних складних одиниць у сучасній українській мові постійно зростає та урізноманітнюється, заповнюючи номінативні лакуни, що постійно виникають. Через це є актуальним студіювання різних типів композитів в українській мові кінця XX - початку XXI ст. Видається необхідним 
виявити основні тенденції динаміки, закономірності оновлення корпусу названої категорії. Адже надзвичайно слушним $\epsilon$ твердження українського лінгвіста С. А. Карпіловської: «Можна без перебільшення стверджувати, що аналіз змін в українській мові зосереджує весь комплекс проблем сучасної мовознавчої науки. Саме цим спричинена увага до мовознавчої динаміки вчених, які працюють у різних мовознавчих галузях: лексикологів, лексикографів, дериватологів, граматистів, ономастів, стилістів і фахівців 3 культури мови. У центрі таких досліджень перебувають передусім інноваційні процеси в мові як один з найактивніших виявів мовної динаміки» [2, с. 3].

Мета статті - виокремлення й аналіз різних типів іменникових композитів-неологізмів, зокрема їх структурних, семантичних та інших особливостей на матеріалі мови сучасних українських 3МI.

Поява й інтенсивне функціонування таких одиниць у мові масмедіа не випадкові: вони становлять найбільш зручний та економний засіб називання різноманітних предметів, понять, явищ, індивідуумів, нерідко ще й із семантико-стилістичною характеристикою. Такі складні інновації відбивають реалізацію в мові важливої тенденції до економії мовних засобів і зусиль, а тому мають також важливе прагматичне значення для дискурсу ЗМІ - економія дорогого ефірного часу та друкованого рядка. У нашій статті поняття «композит» розглядаємо, ідучи за Н. Ф. Клименко [3, с. 262], у вузькому розумінні, тобто це складні слова, утворені основоскладанням.

В аналізований період помітна активізація деривації різних типів нових композитів-іменників, у творенні яких бере участь запозичена чи питома основа. Предметом нашої уваги $\epsilon$ як загальномовні неологізми, так і оказіоналізми.

Загальновідомо, що більшість мовознавців розрізняють основоскладання чисте i складно-суфіксальне, коли основи поєднуються за допомогою інтерфіксів $o, e(\epsilon)$, які дослідники вважають однією 3 основних релевантних ознак таких складних одиниць. Правда, дехто з лінгвістів виділяє ще складно-суфіксальнопрефіксальне основоскладання [1, с. 129].

В українській мові кінця XX - початку XXI ст. засвідчено незначну кількісну перевагу утворень основоскладанням iз суфіксацією (однофракційник, високопосадовець, рідновір'я) над композитами, деривованими чистим основоскладанням (блогосфера, металокрадій, нижчевартість).

Фактичний матеріал засвідчив, що більшість композитівнеологізмів виникає переважно на основі вільних словосполучень, пор.: 
інженерія квіток (квітів) - квіткоінженерія, утворення курсу [валюти] курсоутворення, знати про страви - стравознавство, творення сюжету - сюжетотворення. Помічено, що в останні роки почастішали випадки творення таких одиниць за аналогією й завдяки асоціативному мисленню. Напр.: иінопад, громепад, голепад (пор.: снігопад, листопад); холодомор, кризомор (пор.: голодомор); гречкоїд (пор.: м'ясої); грошописець «фальшивомонетник» (пор.: іконописець); драконоборець (пор.: змієборець) тощо. Однак зафіксовано також нечисленні утворення на основі фразем (відфраземні деривати) - локииновішання (від вішання (вімати) локшини (локшину); новоукраӥнець (від новий украӥнець), грошороб (від робити (зробити) гроші «мати (одержати) якийсь зиск, накопичити кошти, отримати прибутки внаслідок певних дій, операцій, продажу, спекуляцій тощо»), козанострівець (від коза ностра «сицилійська злочинна організація, яку дехто трактує як мафію»). Окремі композити-неологізми виникли в аналізований період завдяки калькуванню: рукоборство (з англ. armwresling від arm - рука і wresling боротьба), новомова (з англ. new speak).

Варто докладніше проаналізувати структурно-словотвірні особливості композитів-неологізмів. Відзначаємо зростання продуктивності ряду компонентів (твірних основ) у нових складних словах, що можуть виступати як у пре-, так і в постпозиції. Серед них в останні десятиліття засвідчено збільшення давнозапозичених і нових іншомовних складників: нафт- (нафтокороль, нафтопромисловик, нафтотрейдер нафтобізнес, нафтомафія); грант- (грантодавець, грантоотримувач, грантопошукувач); грош- (грошодавещь, грошописець); валют- (валютобоязнь, валютодавець, валютотримач); -терапія (глинотерапія, дельфінотерапія, квіткотерапія, словотерапія, шокотерапія), -терапевт (працетерапевт, сміхотерапевт, глинотерапевт), -психолог (народнопсихолог, космопсихолог), -трейдер (зернотрейдер, газотрейдер) тощо. 3-поміж питомих твірних компонентів-основ продуктивними у процесі творення нових композитів у мові сучасних ЗМІ є такі: народ- (народопсихолог, народослужитель, народоборець, народовірещь); нов- (новопризначенець, новорухівець, новокомуніст, новобагатько); украӥн- (україноментальність, украӥноохоронець, украӥноканадець, украӥноненависник, украӥнозневажець, нашоукраїнець); держав- (державознавець, державотворець, державобудівник); влад- (владодержець, владореформатор); творен(програмотворення, підручникотворення, начієтворення); нос(мандатоносець, імідженосець, кийконосець); слов- (слововилив, словообіг, словозбір); вір(а)- (віронетерпимість, рідновір'я, чужовір'я); 
світ- (світотворення, світостановлення, світовідношення, світовлаштування, світолад); сам- (самодіалог, самовозвеличення, саморуйнація, самоошукування, саморозвінчання); -давець (чекодавець, орендодавець, грошодавець, лізингодавець, хабародавець, житлодавець, грантодавець); -люб (каволюб, словолюб, людолюб, душолюб); -творення (державотворення, законотворення, громадянотворення, міфотворення) та ін. Характерно, що більшість наведених вище продуктивних твірних складників і слів виступають ключовими словами зазначеної вище доби. Пор. у контекстах: Влада Азербайджану хотіла підкреслити, щзо дотримується світових тенденцій у боротьбі за екологічно чистий нафтобізнес. gazeta.dt.ua; Дельфінотерапія - новий напрямок реабілітації, щзо праџює в Україні не більще 5 років (www.dcp.org.ua); Украӥноментальність творчих пошуків художника, його прагнення докопатися до коріння $і$ основ начіонального почуття через фольклор свідчить про те, щзо він не пройшов поза тих романтично-екзистенційних ідей, які хвилювали украйнську інтелігенцію на початку ХХ століття (htth://lib.ua-ru.net/inode/19811.html); Однак новобагатько соромиться свого походження $i$ робить усе можливе, щзоб навчитися хороших манер, здобути освіту $i$ близько зійтися 3 представниками вищчого світу (www.zarlit.com/making/373p8.html).

Значна частина іменникових композитів-неологізмів чітко відбивають екстралінгвальні чинники розвитку мови, тобто всі найновіші виклики та віяння новітньої доби, пор.: державотворення, новобагатько, нашоукраӥнець, націєвиховання, кредитоотримувач, інтернетозалежність, моводемократія та багато ін.

За нашими спостереженнями аналізовані слова здебільшого постали на основі кількох словотворчих моделей та словотворчих типів. Варто, на нашу думку, зупинитися на цьому докладніше.

Серед нових іменників-композитів найбільшу кількість становлять одиниці 3 першою субстантивною і другою дієслівною основою, утворені на основі об'єктної синтаксичної конструкції, до складу якої входить опорне дієслово недоконаного виду із залежним іменником, найчастіше без прийменника + певний суфікс. За названою моделлю постали такі продуктивні словотвірні типи на позначення назв осіб, які мають словотвірне значення «особи за певною професією, видом занять, посадою, соціальним станом, дією, поведінкою, рисою характеру, вдачею тощо»: 1) із суфіксом -ець: носити мандат мандатоносець, носити кийок - кийконосець, носити імідж імідженосець, творити добро - добротворець, творити текст (тексти) - текстотворець, писати рими - римописець «поет», давати 
звіт - звітодавець, бороти вогонь - вогнеборець «пожежник», вбивати народ - народовбивець та ін.; 2) із нульовим суфіксом: рубати правду правдоруб, давити кнопку (кнопки) - кнопкодав, робити гондоли гондолороб, жерти гранти - грантожер, жерти рекламу рекламожер та ін.; 3) із суфіксом -ач: отримувати кредит кредитоотримувач, отримувати лізинг - лізингоотримувач, тримати валюту - валютотримач, тримати чеки - чекотримач, иукати стиль стилешукач, встановлювати право - правовстановлювач та ін. Названа вище модель слугувала для продуктивного словотвірного типу на позначення назв конкретних предметів із загальною семантикою «той, що виконує певну дію, має певне практичне призначення» та нульовим суфіксом: ділити борозну - борозноділ, різати плитку - плиткоріз, ловити жучків - жучколов «прилад для ловлення жучків, тобто підслушок», зачіпати трунт - трунтозачепи, возити баржі баржовоз, возити пісок - пісковоз тощо. Засвідчено також малопродуктивний словотвірчий тип із схожим до попереднього значенням та суфіксом -ач: приймати злив - зливоприймач, прокладати курс - курсопрокладач, розкидати сіль - солерозкидач.

Досить значну групу, що постійно поповнюється, серед іменниківновотворів становлять композити, утворені чистим основоскладанням на основі об'єктної конструкції - стрижневого субстантива (переважно віддієслівного), який вимагає іменника у формі родового, знахідного чи орудного відмінка (іноді 3 прийменником). Перший продуктивний словотворчий тип об'єднує нові складні деривати на позначення різноманітних процесів і станів: карбування слів - словокарбування, творення підручників - підручникотворення, творення словників словникотворення, утворення права - правоутворення, утворення слогана - слоганоутворення, поклоніння кумирові (кумирам) кумиропоклоніння, виховання нащії - націєвиховання, споживання ресурсів - ресурсоспоживання, залежність від інтернету інтернетозалежність тощо. До другого малопродуктивного словотворчого типу входять субстантиви-інновації на позначення осіб за певною професією або видом занять: торговець бензином бензоторговець, виробник реклам - рекламовиробник. Засвідчено ще й третій (також малопродуктивний) словотвірний тип із суфіксом -ець, за яким утворено поодинокі складні іменники, із семантикою «назва особи за фахом, певним заняттям, станом, місцем перебування»: зона відчуження-зоновідчуженець, охорона здоров'я-охороноздоровещь.

Своєрідний різновид базових структур становлять займенниковоіменникові об'єктні конструкції, у яких стрижневий іменник (нерідко () О. А. Стишов, 2013. 
віддієслівний) керує залежним займенником у родовому відмінку однини: саморозвінчання - розвінчання самого себе (займенник себе еліптизується). Його реалізує один словотворчий тип на означення опредметненого процесу над самим собою: зомбування самого себе самозомбування, кодування самого себе - самокодування, возвеличення самого себе - самовозвеличення, любування самим собою самолюбування, ошукування самого себе - самоомукування, цезор самого себе - самочезор, імідж самого себе - самоімідж та ін. Такі складні новотвори нерідко виражають іронічну оцінку вчинків і дій певних осіб, напр.: Сьогодні, на жаль, у нас немає ніякої державної мовної політики - лиме істеричні крики "рятуйте!» або зачумлене самозомбування: «наша мова калинова!» (kharakternyk.in.ua/forum/viewtopic.php?id=956); Необхідно навчитися адекватно оцінювати свої можливості, не вдаючись ні до самонищівної критики, ні до самовозвеличення, ні до самолюбування (old.niss.gov.ua/book/panorama/gutsal.htm).

Дещо меншу групу, порівняно 3 попередніми, становлять інноваційні композити, що спираються на атрибутивну синтагму - 3 головним іменником i залежним прикметником. Названі одиниці формують такі продуктивні словотворчі типи: 1) із суфіксом -й- для номінації певного поняття рідна віра - рідновір'я, чужа віра - чужовір'я, пишні слова - пишнослів'я, російська мова - російськомов'я, живі слова живослів'я, старший брат - старшобраття, зрілі літа - зрілоліття та ін.; 2) із суфіксом -ець на позначення особи за певною заняттям, роботою, станом, посадою: вільна боротьба - вільноборець, нове призначення - новопризначенець, висока посада - високопосадовець, «Новий канал»-новоканалець.

Близькою до попередньої словотвірної моделі є структура 3 атрибутивною синтагмою, але вже з головним іменником і залежним порядковим числівником. На іiі основі виник малопродуктивний словотворчий тип із суфіксом -ець на позначення особи за певною ознакою: єдина кров - єдинокровець, єдиний податок єдиноподатківець. Напр.: Не секрет, щзо багато в чому Україна змогла уникнути «безробітних бунтів» завдяки сдиноподатківцям $i$ «тіньовій заробітній платі» (www.personal-plus.net/420/7807.html).

Цікаво, що певна кількість аналізованих одиниць виникла на основі власних назв: «Народна Рада» - народорадівець, Верховна Рада - верховнорадеиьь, «Наша Україна» - нашоукраїнещь, «Весела Січ»-веселосічовик.

Важливо простежити стильові і стилістичні особливості іменникових неологізмів-композитів. Відомо, що в лексиці дискурс 
сучасних 3МІ - це поєднання двох протилежних шарів слів. 3 одного боку, корпус раціональної лексики, скерованої до розуму читачів, слухачів та глядачів. Серед останніх переважають нейтральні слова, а також значною мірою терміни 3 різних галузей знань і діяльності людини. Вони є переконливим свідченням впливу наукового і ділового стилів на публіцистику, зростанням інтелектуалізації як усього українського соціуму загалом, так і окремих громадян зокрема. Так, ізпоміж аналізованих субстантивів виділяємо ряд тематичних груп лексики: науково-технічна (біблієконотонім, родознавство, козакознавство, блогосфера, лезотримач, грунтофрез, иумогасник, повітрозбірник), суспільно-політична (однофракцієц̧ь, намоукраӥнецьь, законотворення, громадянотворення), економічна (єдиноподатківецьь, валютодавець, чековласник, грошопровід), медична (снідоносій, йододифіцит, звукотерапія, тромбоутворення, м'язобіль), релігійна (іконоприхильник, рідновір, храмозвід), спортивна (рукоборство, лижсеролер), офіційно-ділова (документопотік, документообіг, справочинство) й ін., пор.: Багато різних блогів та сайтів люблять сьогодні обмусолювати тему про стан української блогосфери в цілому- існує вона чи ні, розвивається чи в занепаді (webdigest.com.ua/blogosfera/vse-pro-blogy); Йододефіцит призводить до зниження імунітету, щчо автоматично збільиує ризик інфекиійних захворювань (mmo-oz.at.ua/index/chim_nebezpechnij_jododefic); Обсяг документообігу визначають відповідно до кількості вхідних, вихідних та внутріиніх документів за певний період (www.vobu.com.ua/ukr/crib).

3 іншого боку, для урізноманітнення викладу, надання йому свіжості й неординарності, дохідливості, а головне - образності, експресивності й емоційності, щоб дійти не скільки до розуму, а стільки до серця респондентів, публіцисти й автори матеріалів постійно вдаються до творення інновацій. Це зумовлено такою важливою рисою стилю 3МІ, як постійне прагнення i пошук нової маркованості на тлі раціонального стандарту і штампів. Оскільки інформація в публіцистиці завжди розрахована на емоційне сприйняття, то у відповідних контекстах відбувається продукування таких дериватів, які містять у собі не лише змістове, а й стильове навантаження. Публіцисти й дописувачі часто вдається до поєднання іншомовних і власне українських основ або афіксів чи книжного елемента $з$ розмовним (рідше - жаргонним), тобто до незвичного структуруванням різних за семантикою, будовою, стильовою належністю словотворчих одиниць («поєднанням непоєднуваного»), також відтворенням конкретної мовної ситуації, аналогією, асоціативними зв'язками тощо. Так виникають влучні слова- 
характеристики особи (переважно оказіональні), які нерідко виражають певне ставлення до індивіда, події, ситуації, явища: віриоліпецьь «поганий поет», рекламолюб, суржикомовецьь «той, хто розмовляє суржиком», наварообіг, дурносмак, лівосуддя, братопоїдання та ін. Пор.: A от наші рекламолюби завериили огляд передачі (Телеканал «1+1», 21.11.10); Персонаж, Андрій Васильович Суико, як він сам себе називає «мєсний агроном $i$ вправитель», суржикомовець-жертва: "Пан ахвіцер, дозвольте (ukrsence.com.ua/zmist-zhurnalu/ukraïnskij-smisl-1-2012).

У дискурсі сучасних електронних i друкованих ЗМІ для досягення певного стилістичного ефекту автори також вдаються до емоційно-експресиних, образних композитів-запозичень із розмовнопобутового стилю (рідше - стилізації новоутворень під розмовність): кучмовоз «двоколісний візок середнього розміру для перевезення пакунків 3 одягом, речами», зомбоячиик «телевізор», кнопкодав, дурнороб, жабодуха «задрість, жадібність», членовозка та ін. Пор.: Добрий попит і ціну мають ручні двоколісні візки, яких колись не робили. Легка, делікатна, складана - то кравчучка. Давня народна назва «бідка» відмирає. Тяжкий залізний кучмовоз здатний витримати і иентнер - то вже справжня біда («Поступ», 25.05.01); Виявилось, щуо [Рівненська] обласна рада переймає досвід своїх колег з Верховної Ради, коли депутати при голосуванні тиснуть на кнопки та приймають рішення замість відсутніх однопартійиів. Після скарг на «кнопкодавів» від опозичійних депутатів голова облради провів перереєстрацію («Рівне вечірнє», 28.04.11). Використання розмовних одиниць також зумовлене іншою визначальною ознакою аналізованого стилю - намаганням демократизувати та урізноманітнити виклад матеріалу, зробити його дохідливішим для пересічного громадянина, вплинути на емоції сприймача інформації, зацікавити його, переконати, спонукати до співпереживання, співчуття або викликати почуття неприйняття, осуду, зневаги тощо.

Спостереження над мовним матеріалом сучасних мас-медіа засвідчує, що з-поміж усіх нових маркованих назв істотно домінують одиниці негативно-оцінного характеру, серед яких переважають осудливі, іронічні, зневажливі, лайливі та навіть вульгарні слова: пустомова, народовбивця, жлоболюди, украӥнозневажець, украӥнохульник, україножер, лохомукач, довбодзьоб. Напр.: - У вамій книюсиі є окремий розділ про формування Сталіна як народовбивці. Які ж чинники спричинилися до цуього? (day.kiev.ua); Сам намісник Галичини, тобто периа особа після изісаря, граф Бадені, завзятий україноюсер, доияільно затримав стару систему виборів (www.ji.lviv.ua/n63texts/hajda.htm). Це 
відбувається тому, що більшість сучасних ЗМІ відбивають політичну, ідеологічну, етнічну, конфесійну боротьбу, продукують нерідко так званий «чорний піар», а іноді навіть потакають низьким смакам мовців, моді на знижене й вульгарне.

Інновацій позитивно-оцінного характеру нами зафіксовано значно менше: душеопікун, блакитнопрапорник «член ЄС», хліботворець, землетрудич та ін. Пор.: Що я селянка, донька хліботворця, Секрету 3 того зовсім не роблю. Люблю їі, як хліб святий, як сонще. Себе за неї без вагань спалю («Енергія», №9 (169), вересень 2011); Культ успіху й багатства захопив землі землетрудичів. Зранку до ночі через телевізор ми споживаємо своє, вірніше, чуже гламурне щзастя («Пенсія», №88, лютий 2011).

Виявлено, що в сучасних українських мас-медіа найактивніше творяться й функціонують іменникові композити-неологізми в: а) заголовках, лідах газет і журналів, назвах теле- і радіопередач, програм тощо: Вертоліт-«водожер» (заголовок статті, «Україна молода», 10.06.05, с. 3); Невсипуще телеоко (заголовок статті, «Столиця», 14-20.12.01, с. 28); «Цифросвіт» (назва телепередачі); «Вусолапохвіст» (назва телепередачі); «Відеольох» (назва музичної передачі); б) у гумористично-сатиричному дискурсі: Голопупія, Моворосійськ (Напр.: Мій краӥна Голопупія живе добре! Пише Вам зять Омумбо Бонісімо Мутак голопупенко з Африки (Укр. радіо, 21.04.04, о 9.12); в) дитячих газетах, журналах, передачах, мультфільмах: драконоборецьь, запахобачення, радіоерик, дуркобол (Напр.: - Що ти робиш? - Винаходжу дуркобол (Телебачення, ICTV, 17.02.02, о 17.46); - Ми не миші, а радіоерики! (Укр. радіо, 13.09.03, о 9.07); г) мові реклами: осінній цінопад та ін.

Цікаво, що серед аналізованих одиниць трапляються також i синонімічні утворення. Так, на позначення «народного депутата Верховної Ради України та інших рад» функціонують одиниці, на зразок: верховнорадівець, значконосець, мандатоносець, білетоносець, кнопкодав. Крім композита верховнорадівець, усі інші містять негативну оцінну семантику з відтінком іронії: Як бачимо, вульгарний криміналітет, той, щз був з татуюванням $i$ певним жаргоном, переходить під знамена «значконосців» різних рівнів, починаючи від районних рад («Народна газета», 15.03.97); Волаючи про сочуіальний захист малозабезпечених, мандатоносці захистили передусім себе, встановивши собі високу платню та всілякі пільги і відгородивиисьвід відповідальності перед Законом депутатською недоторканістю («Вечірній Київ», 19.09.95); Другий секретар обкому коцьюбиної партії 
переконує вибориів, щзо в нинішній Верховній Раді майже нема «справжніх» комуністів, самі лише «запроданщі, білетоносці», які два роки тому здали свою партію ні за цапову душу, а оці, легалізовані такі справжні («Народна газета», №10(141), 1994).

Досліджено, що серед аналізованих утворень переважають іменники на позначення осіб, меншу групу становлять номінації конкретних предметів, назви абстрактних понять, процесів тощо.

Отже, іменникові композити-неологізми в мові сучасних 3МІ розкривають невичерпні системні й асистемні можливості українського словотвору, виражально-зображальні інтенції мови. Надалі також варто глибше простудіювати такі одиниці в слов'янських, германських і романських мовах у зіставному аспекті.

\section{Література}

1. Горпинич В. О. Сучасна українська літературна мова : Морфеміка. Словотвір. Морфонологія : [підручник] / В. О. Горпинич. - К. : Вища школа, 1999. - 207 с.

2. Карпіловська Є. Зміни в структурі сучасної української мови та можливості їх моделювання / Є. А. Карпіловська //Українська мова. - 2011. - С. 3-18.

3. Клименко Н. Ф. Композит / Н. Ф. Клименко // Українська мова : Енциклопедія / редкол. : В. М. Русанівський, О. О. Тараненко (співголови), М. П. Зяблюк та ін. - [2-ге вид., випр. і доп.]. - К. : Вид-во «Укр. ен-дія» ім. М. П. Бажана, 2004. - С. 262-264.

Стаття надійшла до редакції 18.10 .2013 р. 